\title{
Simulasi Handover Pada ASN-GW (Access Service Network-Gateway) WiMAX (Worldwide Interoperability Microwave Access)
}

\author{
Rita Novalia Sari ${ }^{[1]}$, Herlinawati ${ }^{[2]}$, Yetti Yuniati ${ }^{[3]}$ \\ 1,2,3 Jurusan Teknik Elektro Fakultas Teknik Universitas Lampung \\ 1rita_trans32@yahoo.co.id, ${ }^{2}$ herlinawati@unila.ac.id. ${ }^{3}$ yetti@unila.ac.id
}

\begin{abstract}
Abstrak
WiMAX dengan standar IEEE 802.16e merupakan suatu standar untuk sistem mobile WiMAX. Dalam sistem mobile ini mengenal adanya sistem handover. Simulasi pada penelitian ini terdapat 2 skenario, yang sama-sama menggunakan ASN-GW. Simulasi terdiri dari intra ASN-GW dan inter ASN-GW. Hasil dari simulasi yang telah dilakukan pada intra ASN-GW menunjukkan grafik throughput yang memperlihatkan terjadinya handover dari masing-masing nodal yang terlibat.
\end{abstract}

Kata kunci: mobile, handover, VoIP, intra ASN-GW, inter ASN-GW, throughput.

\begin{abstract}
WiMAX with IEEE 802.16e standard is the standard for mobile WiMAX system. In this mobile system there are handover system. Simulation at this project have 2 scenario that used ASN-GW. Simulation are intra ASNGW and inter ASN-GW. Result from simulation that used at intra ASN-GW showing handover happened from each node that belong.
\end{abstract}

Key words: mobile, handover, VoIP, intra ASN-GW, inter ASN-GW, throughput

\section{PENDAHULUAN}

Dunia telekomunikasi saat ini tengah mengembangkan teknologi WiMAX, begitu juga dengan Indonesia. Teknologi ini merupakan teknologi yang sebelumnya berada pada standar WMAN kemudian WiMAX diambil ahli oleh IEEE dan oleh ETSI HiperMAN. WiMAX pada akhir tahun 2005 menggunakan standar untuk WiMAX mobile yaitu IEEE 802.16e. Teknologi ini mendukung proses pentransmisian signal yang bersifat LOS dan NLOS.

Dalam teknologi WiMAX wireless standar 802.16e perangkat yang terdapat didalamnya, yaitu: MS, BS, ASN, dan CSN. Fungsi dari masing-masing perangkat yaitu MS berfungsi sebagai pengguna jaringan; BS berfungsi sebagai tempat mengontrol semua MS; ASN merupakan suatu perangkat yang terdiri dari beberapa BS dan terdapat beberapa ASN-GW; dan CSN adalah pusat dari perkumpulan ASN yang berfungsi sebagai penyedia layanan koneksi internet.

Dalam hal ini, user sudah tentu akan berpindah-pindah dari satu tempat ke tempat yang lain dan tentunya frekuensi akan berkurang dari BS yang satu ke yang lainnya namun komunikasi yang diinginkan tidak pernah putus karena yang diharapkan kekontinuitasan dalam berkomunikasi. Dalam penelitian ini akan dibahas mengenai handover dengan layanan VoIP yang diberikan, pada intra 
dan inter ASN-GW yang satu ke yang lainnya.

\section{TINJAUAN PUSTAKA}

\section{A. WIMAX}

Implementasi teknologi nirkabel pada umumnya memerlukan adanya jalur line of sight antara pengirim dan penerima, jika terdapat kondisi NLOS maka akan menimbulkan redaman propagasi yang akan menurunkan kualitas pensinyalan. Teknologi WiMAX menawarkan kemampuan untuk bekerja secara baik pada kondisi NLOS dengan beberapa fitur tambahan yang berkualitas didukung oleh penerapan teknologi OFDM dan OFDMA. Metode OFDM yang digunakan untuk WiMAX adalah Fast Fourier Transform 256. Fitur PHY untuk sistem duplex pada stándar WiMAX bisa diterapkan pada Frequency Division Duplexing dan Time Division Duplexing atau keduanya TDD dan FDD.

Mobile WiMAX menyediakan fitur handal mendukung pemakaian baterai yang lebih lama yakni penghematan daya.

WiMAX MAC protokol didesain untuk aplikasi PMP. Digunakan dua jalur data berkecepatan data tinggi untuk komunikasi dua arah antara BS dan SS, masing-masing disebut Uplink untuk komunikasi menuju ke BS, dan Downlink untuk komunikasi dari BS. Pada penggunaan sistem TDD, ditentukan periode transmit untuk DL dan UL. Protokol MAC 802.16 merupakan connection oriented.

Mobile WiMAX beroperasi pada frekuensi $2-4 \mathrm{GHz}$. Semakin besar frekuensi, daya yang diterima akan semakin rendah, padahal daya yang ditransmisikan oleh sistem wireless seringkali terbatas bergantung pada lingkungan dan regulasi pemerintah. Oleh karena itu, jangkauan mobile WiMAX akan lebih kecil, sehingga untuk luas jangkauan yang sama, base station yang dibutuhkan mobile WiMAX lebih banyak.

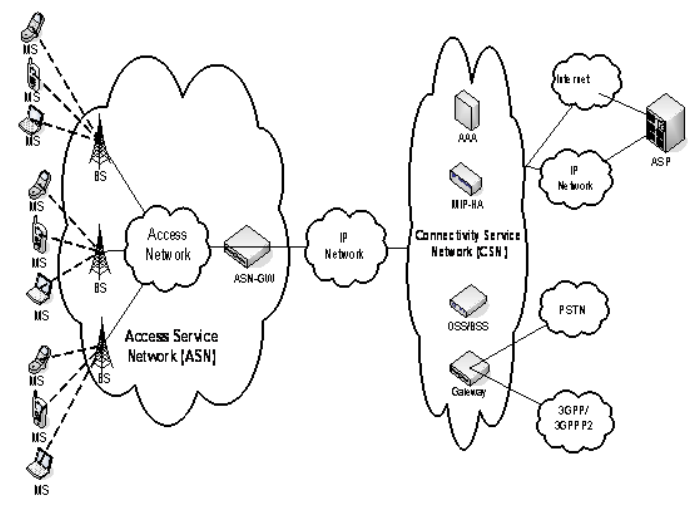

Gambar 1. Arsitektur jaringan WiMAX

Konfigurasi WiMAX terdiri dari:

\section{Base Station}

Base Station memiliki membangun hubungan dengan mobile station. BS juga memiliki fungsi lain yaitu mengatur micromobility management seperti proses handover, radio resource management.

\section{ASN-GW}

ASN Gateway adalah entitas logic yang merepresentasikan sebuah gabungan dari entitas-entitas fungsional control plane yang berkomunikasi dengan BS, CSN atau dengan ASN lainnya.

\section{CSN}

Penyedia layanan konektivitas CSN ke sebuah jaringan internet, ASP, jaringan public lainnya, dan yang berhubungan dengan jaringan.

\section{B. HANDOVER}

Handover adalah proses pengalihan kanal traffic secara otomatis dalam system 
seluler untuk menjamin adanya kontinuitas komunikasi apabila pelanggan bergerak dari satu sel ke sel yang lain pada MS yang sedang digunakan untuk berkomunikasi tanpa terjadinya pemutusan hubungan. Pergerakan user mengakibatkan perubahan yang dinamis terhadap kualitas link dan tingkat interferensi dalam sistem, sehingga dibutuhkan mekanisme perancangan handover yang handal dan dapat meningkatkan performansi jaringan.

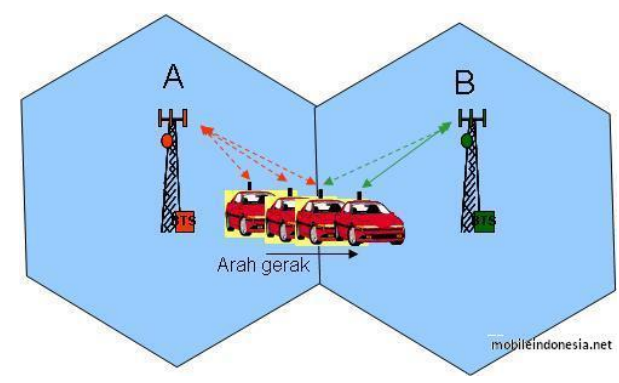

Gambar 2. Handover pada MS

Mobile Station bergerak menjauhi suatu cell maka daya yang diterima oleh MS akan berkurang. Jika MS bergerak semakin menjauhi Base Station maka daya pancar akan semakin berkurang. Menjauhnya MS pada cell asal menjadikan MS mendekati cell lainya. Cell lainnya dikatakan sebagai cell kandidat yaitu cell yang akan menerima pelimpahan MS dari cell sebelumnya. Diantara cell kandidat yang menerima daya pancar MS terbesar maka pelimpahan MS akan berada pada cell tersebut. Cell kandidat yang menerima pelimpahan MS akan melakukan monitoring.

\section{CODEC}

Codec adalah metode untuk mengkompres sinyal digital agar ukurannya lebih kompak. Codec bertujuan untuk mengurangi penggunaan bandwidth di dalam transmisi sinyal pada setiap panggilan dan sekaligus berfungsi untuk meningkatkan jumlah panggilan. ITU-T membuat beberapa standar untuk voice codec yang direkomendasikan untuk implementasi VoIP.

G.711

G.711 suatu standar Internasional untuk kompresi audio dengan menggunakan teknik Pulse Code Modulation dalam pengiriman suara dengan bit rate $64 \mathrm{kbps}$, ini merupakan standar transmisi untuk satu kanal telepon digital. Percakapan berupa sinyal analog mengalami kompresi dan pengkodean menjadi sinyal digital oleh PCM G.711 sebelum memasuki VoIP gateway.

\section{Parameter Kinerja Jaringan}

\section{Throughput}

Ukuran dari transfer bit di media selama jangka waktu tertentu. Throughput biasanya tidak sesuai dengan bandwidth yang ditentukan dalam implementasi lapisan fisik.

\section{Packet Loss}

Probabilitas packet hilang sewaktu transit dari source ke destination. Sinyal suara pada telepon internet akan ditransmisikan dalam jaringan berbasisi IP dalam bentuk paket-paket IP.

Tabel 1.Standar Tingkat Packet Loss

\begin{tabular}{|c|c|}
\hline Tingkat paket hilang & Kualitas \\
\hline $0-1 \%$ & Baik \\
\hline $1-2 \%$ & Cukup \\
\hline$>2 \%$ & Buruk \\
\hline
\end{tabular}

\section{Delay}

Penjumlahan dari waktu tunda pemrosesan, waktu tunda paketisasi, waktu tunda antrian, dan waktu tunda akibat jitter buffer di sisi penerima. Waktu tunda sangat mempengaruhi kualitas layanan suara. ITU 
G.114 membagi karakteristik waktu tunda berdasarkan tingkat kenyamanan $u s e r$.

Tabel 2. Pengelompokan Waktu Tunda berdasarkan ITU-T G.114

\begin{tabular}{|l|c|}
\hline \multicolumn{1}{|c|}{$\begin{array}{c}\text { Waktu } \\
\text { Tunda }\end{array}$} & Kualitas \\
\hline $0-150 \mathrm{~ms}$ & Baik \\
\hline $150-300 \mathrm{~ms}$ & $\begin{array}{c}\text { Cukup, masih dapat } \\
\text { diterima }\end{array}$ \\
\hline$>300 \mathrm{~ms}$ & Buruk \\
\hline
\end{tabular}

\section{Jitter}

Perbedaan selang waktu kedatangan antar paket di terminal tujuan. Jitter dapat disebabkan oleh terjadinya kongesti, kurangnya kapsitas jaringan, variasi ukuran paket, serta ketidakurutan paket. Faktor ini diperhitungkan karena karakteristik komunikasi voice adalah sensitif terhadap waktu tunda dan jitter.

Tabel 3. Standar Jitter

\begin{tabular}{|c|c|}
\hline Jitter & Kualitas \\
\hline $0-20 \mathrm{~ms}$ & Baik \\
\hline $20-50 \mathrm{~ms}$ & Cukup \\
\hline$>50 \mathrm{~ms}$ & Buruk \\
\hline
\end{tabular}

E. Software Pendukung

Software yang digunakan dalam pengerjaan skripsi ini, Opnet Modeler 14.5. Fitur-fitur yang terdapat di dalam software ini memudahkan pengguna untuk menjalankan simulasi yang akan dilakukan.

Dalam pemodelan hirarki OPNET Modeler menggunakan beberapa notasi untuk memodelkan sebuah jaringan, node, atau proses.

\section{PERANCANGAN SIMULASI}

Simulasi yang akan dilakukan terdiri dari 2 skenario, yaitu intra ASN-GW dan inter ASN-GW. Kedua simulasi tersebut menggunakan standar IEEE 802.16e untuk perancangan simulasinya, berikut standar yang digunakan dalam perancangan yang disajikan dalam bentu tabel.

\section{Standar Mobile Station}

Tabel 4. Standar Mobile

\begin{tabular}{|l|l|l|}
\hline No & $\begin{array}{l}\text { Parameter berdasar } \\
\text { IEEE 802.16e }\end{array}$ & \multicolumn{1}{|c|}{ Value } \\
\hline 1. & PHY Profile & $\begin{array}{l}\text { WirelessOFDMA } \\
\text { 20MHz }\end{array}$ \\
\hline 2. & $\begin{array}{l}\text { Modulasi dan } \\
\text { Coding }\end{array}$ & Adaptive \\
\hline
\end{tabular}

\section{Standar Base Station}

Tabel 5. Standar Base Station

\begin{tabular}{|l|l|l|}
\hline No. & $\begin{array}{c}\text { Parameter berdasar } \\
\text { IEEE 802.16e }\end{array}$ & \multicolumn{1}{|c|}{ Value } \\
\hline 1. & PHY Profile & $\begin{array}{l}\text { WirelessOFDMA } \\
\text { 20MHz }\end{array}$ \\
\hline
\end{tabular}

Layanan Aplikasi VoIP

Tabel 6. Standar Layanan Aplikasi VoIP

\begin{tabular}{|l|l|l|}
\hline No. & $\begin{array}{l}\text { Parameter berdasar IEEE } \\
802.16 \mathrm{e}\end{array}$ & \multicolumn{1}{|c|}{ Value } \\
\hline 1. & Encoder Scheme & $\mathrm{G} .711$ \\
\hline 2. & Voice Frame per Packet & 1 \\
\hline 3. & Type of Service & $\begin{array}{l}\text { Interactive } \\
\text { Voice }\end{array}$ \\
\hline 4. & $\begin{array}{l}\text { Compression Delay } \\
\text { (seconds) }\end{array}$ & 0.02 \\
\hline 5. & $\begin{array}{l}\text { Decompression Delay } \\
\text { (seconds) }\end{array}$ & 0.02 \\
\hline
\end{tabular}

Tabel 7. Parameter Class MAC Service

\begin{tabular}{|l|l|c|}
\hline No. & $\begin{array}{l}\text { Parameter berdasar } \\
\text { IEEE 802.16e }\end{array}$ & Value \\
\hline 1. & Type Scheduling & UGS \\
\hline
\end{tabular}




\begin{tabular}{|l|l|l|}
\hline 2. & $\begin{array}{l}\text { Maximum sustained } \\
\text { traffic rate }\end{array}$ & $5 \mathrm{Mbps}$ \\
\hline 3. & $\begin{array}{l}\text { Maximum reserved } \\
\text { traffic rate }\end{array}$ & $1 \mathrm{Mbps}$ \\
\hline 4. & Maximum Latency & $30 \mathrm{~ms}$ \\
\hline 5. & Maximum Traffic Burst & 0 \\
\hline 6. & Unsolicited Poll Interval & $\begin{array}{l}\text { Auto } \\
\text { Calculated }\end{array}$ \\
\hline
\end{tabular}

Parameter PHY Layer WiMAX

Tabel 8. Parameter PHY Layer WiMAX

\begin{tabular}{|l|l|l|}
\hline No. & $\begin{array}{l}\text { Parameter berdasar } \\
\text { IEEE 802.16e }\end{array}$ & Value \\
\hline 1. & Frame Duration & $5 \mathrm{~ms}$ \\
\hline 2. & Symbol Duration & $102.8 \mathrm{~ms}$ \\
\hline 3. & Jumlah Subscriber & 2048 \\
\hline 4. & Teknik Duplexing & TDD \\
\hline 5. & Base Frekuensi & $5 \mathrm{GHz}$ \\
\hline 6. & Bandwidth & $20 \mathrm{MHz}$ \\
\hline 7. & Modulasi & Adaptive \\
\hline 8. & Number Of Transmitter & MIMO \\
\hline
\end{tabular}

Simulasi yang akan dilakukan terdiri dari 2 skenario seperti yang telah disebutkan sebelumnya, adapun gambar dari perancangan yang telah dilakukan adalah seperti gambar di bawah ini.

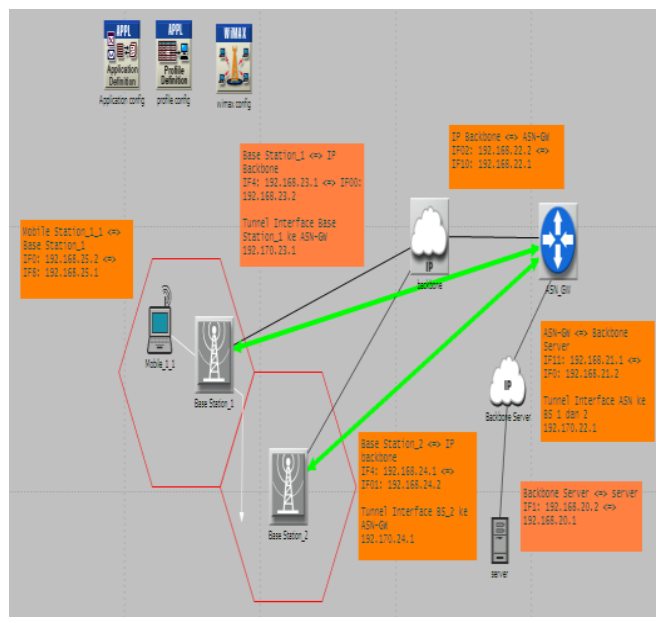

Gambar 3. Skenario intra ASN-GW

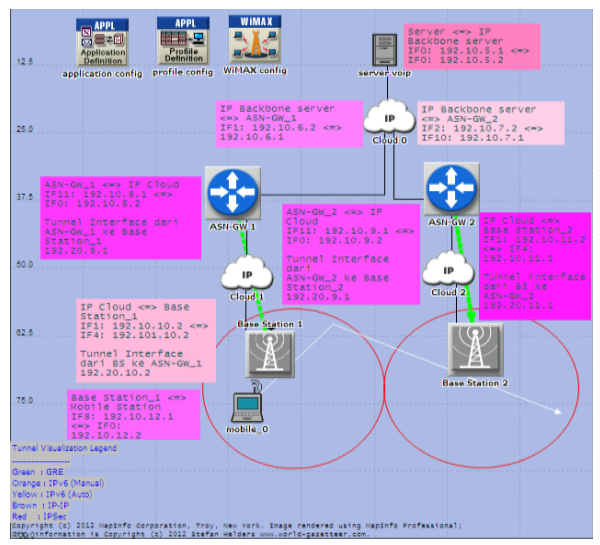

Gambar 4. Skenario inter ASN-GW

\section{HASIL DAN ANALISA}

Hasil dari simulasi yang telah dilakukan didapati grafik sebagai berikut:

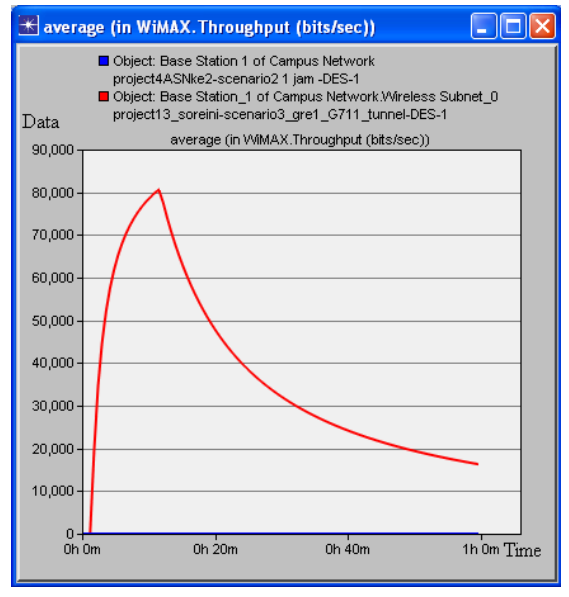

Gambar 5. Grafik pada BS_1

Gambar 5 merupakan grafik yang dihasilkan oleh 2skenario intra dan inter ASN-GW dengan garis berwarna merah, awal simulasi nilai throughput 4,29 bit/sec sampai pada menit ke 1 naik, nilai throughput sebesar $80.537 \mathrm{bit} / \mathrm{sec}$ di menit ke 11 dan grafik terus menurun sampai akhir simulasi nilai throughput 16.337 bit/sec. Garis berwarna biru merupakan hasilsimulasi inter ASN-GW nilai throughput tidak ada. Simulasi pada inter ASN-GW ini tidak berhasil mengeluarkan throughput karena simulator yang kurang support dengan 2 ASN-GW. 


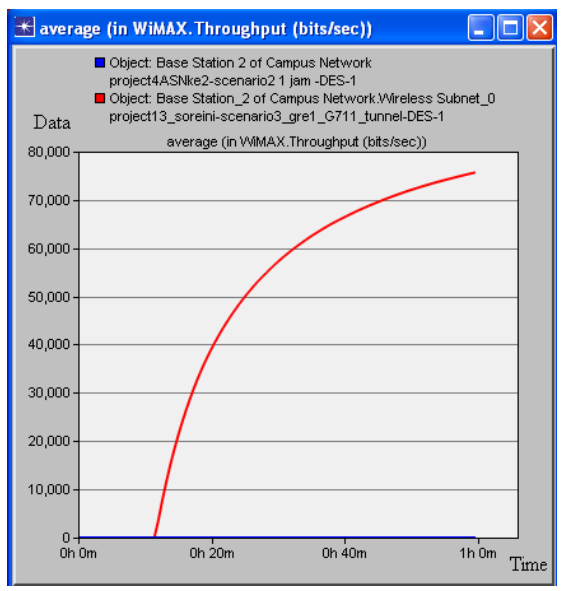

Gambar 6. grafik pada BS_2

Untuk intra ASN-GW simbol warna merah. Nilai maksimum throughput 75.626 bps dengan nilai 0 awal simulasi, naik pada menit ke 11 . Untuk simulasi skenario ke 2 nilai yang dihasilkan tidak ada.

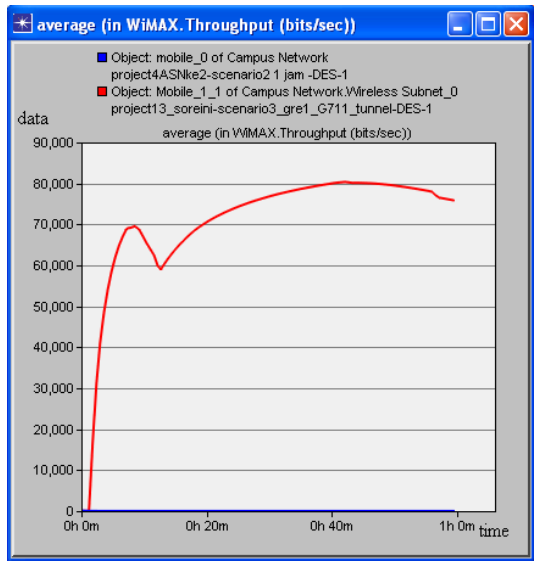

Gambar 7. grafik pada MS

Grafik dengan simbol berwarna merah pada Grafik MS merupakan simulasi yang dilakukan pada intra ASN-GW. Dari grafik terlihat, saat simulasi dilakukan selama 1 jam, throughput mulai muncul pada menit ke 1 dan terus naik sampai menit ke 9 dengan nilai 69.530 bps. Pada menit ke 12 terjadi penurunan nilai throughput pada nilai 58.966 bps. Namun, nilai kembali naik sebesar 80.127 bps.

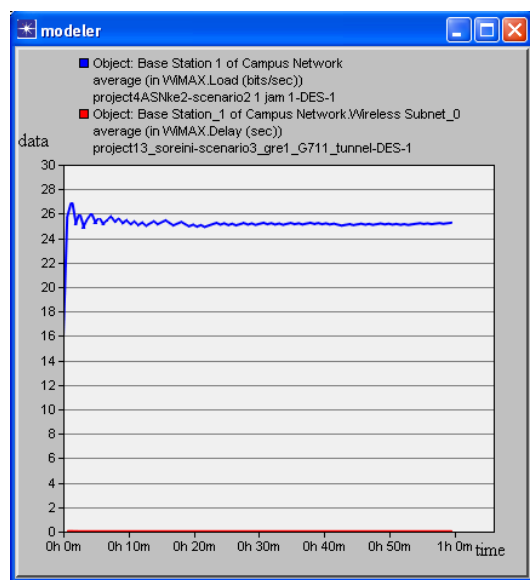

Gambar 8. WiMAX Delay BS_1

Gambar di atas menampilkan grafik pada skenario intra dan inter ASN-GW. Delay pada intra ASN-GW selama 0.029 sec pada awal simulasi. Selama simulasi terjadi penurunan delay, menjadi 0.017 sec. Simulasi inter ASN-GW, delay yang dihasilkan pada awal simulasi berada pada nilai $26,96 \mathrm{bit} / \mathrm{sec}$, kemudian stabil pada nilai $25,25 \mathrm{bit} / \mathrm{sec}$. Nilai delay yang terjadi tidak akan dirasakan oleh user. Sehingga user dapat berkomunikasi dengan baik tanpa gangguan. Berikut tabel untuk melihat nilai pada simulasi intra dan inter ASN-GW.

Tabel 9. Delay BS_1

\begin{tabular}{|c|c|c|}
\hline Base Station_1 & Minimum & Maksimum \\
\hline Intra $A S N-G W$ & $0,017 \mathrm{sec}$ & $0,029 \mathrm{sec}$ \\
\hline Inter $A S N-G W$ & $25,25 \mathrm{sec}$ & $26,69 \mathrm{sec}$ \\
\hline
\end{tabular}

Nilai delay yang dihasilkan pada kedua simulasi tersebut masih dalam batas yang baik untuk terjadinya delay.

Gambar 9. merupakan delay yang terjadi pada intra ASN-GW. Delay terjadi pada menit ke 12. Nilai delay pada saat terjadi handover yaitu berada pada nilai 0.017. Untuk inter ASN GW tidak dapat ditampilkan karena data untuk delay yang tidak dapat keluar saat dilakukan visualisasi grafiknya. 


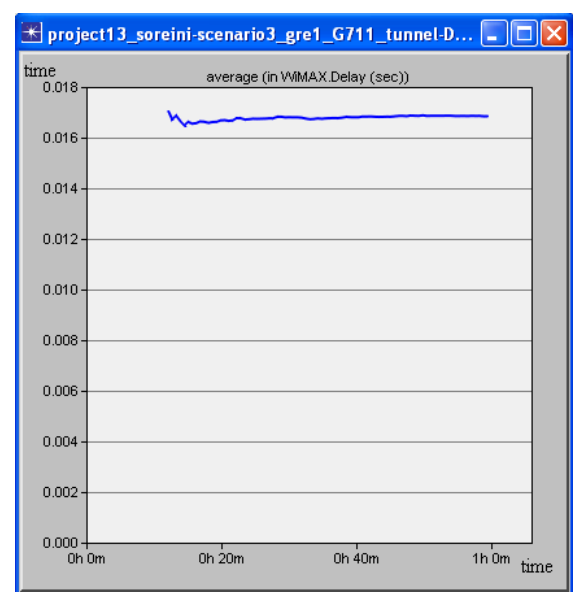

Gambar 9. WiMAX Delay BS_2

Pada Gambar 10. delay yang terjadi pada MS dengan simulasi pada intra dan inter ASN GW. Grafik berwarna merah merupakan delay pada intra ASN GW. Dari awal simulasi delay berada pada nilai 0,0031 sec. Nilai delay naik menjadi 0,016 sec pada menit ke 7 simulasi dan turun selama simulasi berlangsung dan diakhir simulasi pada nilai $0,0060 \mathrm{sec}$.

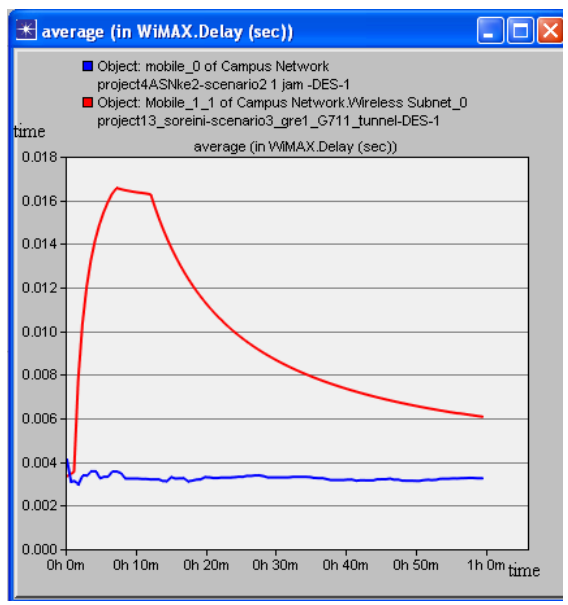

Gambar 10. Delay pada MS

Pada garis berwarna biru merupakan simulasi yang terjadi pada inter ASN GW. Grafik pada inter ASN GW untuk delay $0,0023 \mathrm{sec}$. Dari grafik, delay berada pada nilai rata-rata $0,0030 \mathrm{sec}$.
Di bawah ini tabel yang berisikan nilai minimum dan maksimum dari delay pada MS.

Tabel 10. Delay pada MS

\begin{tabular}{|c|c|c|}
\hline Mobile Station & Minimum & Maksimum \\
\hline Intra ASN GW & $0,0031 \mathrm{sec}$ & $0,0161 \mathrm{sec}$ \\
\hline Inter ASN GW & $0,0023 \mathrm{sec}$ & $0,0038 \mathrm{sec}$ \\
\hline
\end{tabular}

Pada Gambar 11 simbol berwarna merah merupakan grafik pada intra ASNGW. Dari hasil grafik data dropped terjadi pada menit ke 11 dengan nilai data yang hilang sebesar 5650 bit/sec. Dari menit ke 11 data dropped menurun sampai akhirnya di menit ke 55 dengan nilai data yang hilang sebesar 1336 bit/sec, kemudian nilai data dropped naik lagi pada menit 57 dengan nilai 2627 bit/sec. Nilai data dropped untuk inter ASN-GW tidak ada.

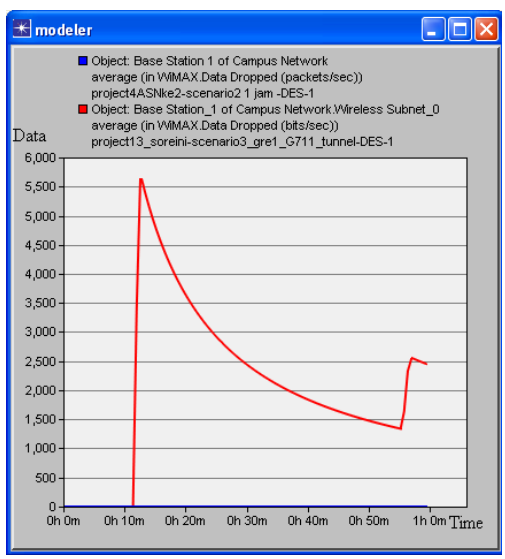

Gambar 11. Data dropped BS_1

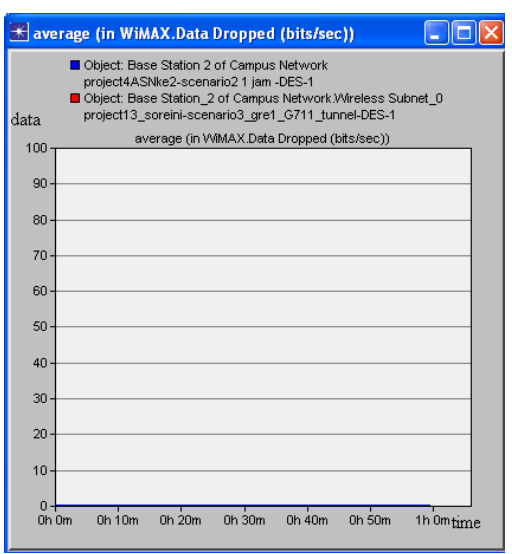

Gambar 12. Data dropped BS_2 
Gambar 12 merupakan data dropped yang terjadi pada 2 simulasi. Kedua simulasi sama-sama menampilkan data dropped dengan nilai 0 bps dari awal sampai dengan akhir simulasi.

Berdasarkan grafik Gambar 13, terdapat 2 jenis grafik dengan data yang diamati sama. Untuk garis berwarna merah merupakan simulasi pada intra ASN GW. Data dropped pada MS dari awal simulasi berada pada nilai 0 , yang berarti tidak ada data yang hilang, pada menit ke 11 terjadi peningkatan nilai data dropped sebesar 5,07 bps sampai menit ke 12 simulasi. Data dropped berangsur-angsur turun menuju 0 sampai pada akhir simulasi nilai data yang hilang 1,0667 sec.

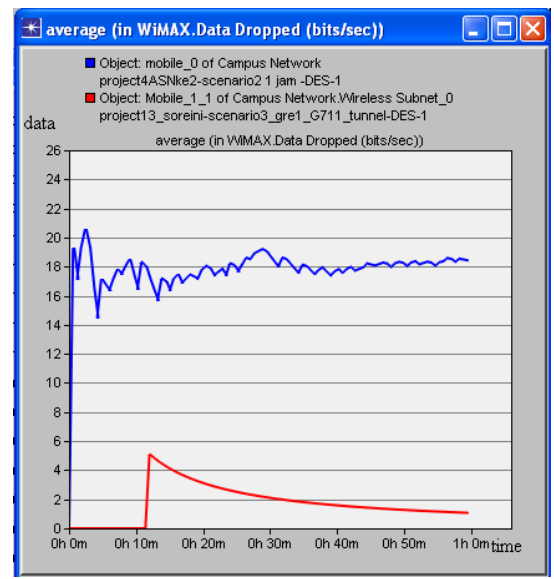

Gambar 13. Data dropped pada MS

Pada simulasi inter ASN-GW nilai data dropped yang dihasilkan lebih besar dibandingkan simualsi intra ASN GW. Dari awal simulasi dibangkitkan nilai data dropped berada pada posisi 0 dan ketika simulasi berjalan selama 1 jam, grafik yang dihasilkan untuk data dropped memberikan nilai rata-rata yaitu sebesar 18 bps. Berikut akan ditampilkan tabel mengenai data dropped.
Tabel 11. Data dropped pada MS

\begin{tabular}{|l|l|l|}
\hline Mobile Station & Minimum & Maksimum \\
\hline Intra ASN GW & 0 bps & $5,07 \mathrm{bps}$ \\
\hline Inter ASN GW & 0 bps & $18,83 \mathrm{bps}$ \\
\hline
\end{tabular}

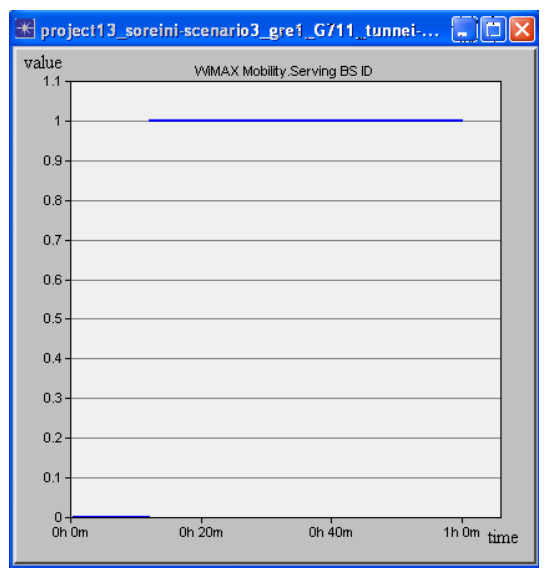

Gambar 14. Serving BS ID

Gambar 14 menampilkan grafik serving BS ID. Serving ID yang dimaksudkan untuk menampilkan BS ID dari arus serving ID pada Mobile Station. Grafik yang terlihat merupakan serving ID untuk simulasi intra ASN-GW. Pada saat melakukan pengaturan parameter MAC BS diatur dengan nilai 0 untuk BS serving dan nilai 1 untuk BS target.

Namun lain halnya dengan inter ASN-GW, tidak dapat menampilkan serving BS ID nya.

Dengan melakukan variasi pada kecepatan MS jelas akan mempengaruhi kualitas layanan yang terjadi pada MS yang sedang bergerak. Variasi gerak dilakukan dengan kecepatan 10 km/jam, 30 $\mathrm{km} / \mathrm{jam}, 50 \mathrm{~km} / \mathrm{jam}$, dan $70 \mathrm{~km} / \mathrm{jam}$. 


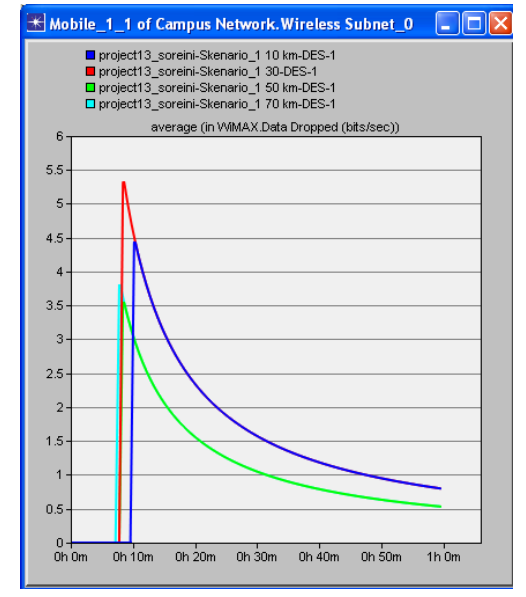

Gambar 15. Data dropped pada MS dengan variasi kecepatan

Pada mobile, data dropped yang terjadi untuk kecepatan yang berbeda sama-sama memberikan nilai data yang hilang, seperti yang tampak pada Gambar 11 dapat dilihat, bahwa data dropped yang terjadi pada kecepatan mobile yang berbeda.

Tabel 12. Data dropped pada variasi kecepatan mobile

\begin{tabular}{|c|c|c|}
\hline $\begin{array}{c}\text { Kecepatan } \\
\text { pada MS }\end{array}$ & Minimum & Maksimum \\
\hline $10 \mathrm{~km} / \mathrm{jam}$ & $0 \mathrm{bit} / \mathrm{sec}$ & $4,44 \mathrm{bit} / \mathrm{sec}$ \\
\hline $30 \mathrm{~km} / \mathrm{jam}$ & $0 \mathrm{bit} / \mathrm{sec}$ & $5,33 \mathrm{bit} / \mathrm{sec}$ \\
\hline $50 \mathrm{~km} / \mathrm{jam}$ & $0 \mathrm{bit} / \mathrm{sec}$ & $3,55 \mathrm{bit} / \mathrm{sec}$ \\
\hline $70 \mathrm{~km} / \mathrm{jam}$ & $0 \mathrm{bit} / \mathrm{sec}$ & $3,80 \mathrm{bit} / \mathrm{sec}$ \\
\hline
\end{tabular}

Dari tabel data dropped dapat dilihat bahwa nilai maksimum dari masing-masing kecepatan yang bervariasi memberikan nilai data dropped yang bervariasi juga.

Untuk delay yang dihasilkan dari variasi kecepatan MS tidak begitu besar delay yang terjadi, nilai dari delay ditampilkan seperti pada tabel di bawah ini.
Tabel 13. Delay pada variasi kecepatan mobile

\begin{tabular}{|c|c|c|}
\hline $\begin{array}{c}\text { Kecepatan } \\
\text { pada MS }\end{array}$ & Minimum & Maksimum \\
\hline $10 \mathrm{~km} / \mathrm{jam}$ & $0,0033 \mathrm{sec}$ & $0,0164 \mathrm{sec}$ \\
\hline $30 \mathrm{~km} / \mathrm{jam}$ & $0,0034 \mathrm{sec}$ & $0,0164 \mathrm{sec}$ \\
\hline $50 \mathrm{~km} / \mathrm{jam}$ & $0,0034 \mathrm{sec}$ & $0,0164 \mathrm{sec}$ \\
\hline $70 \mathrm{~km} / \mathrm{jam}$ & $0,0033 \mathrm{sec}$ & $0,0164 \mathrm{sec}$ \\
\hline
\end{tabular}

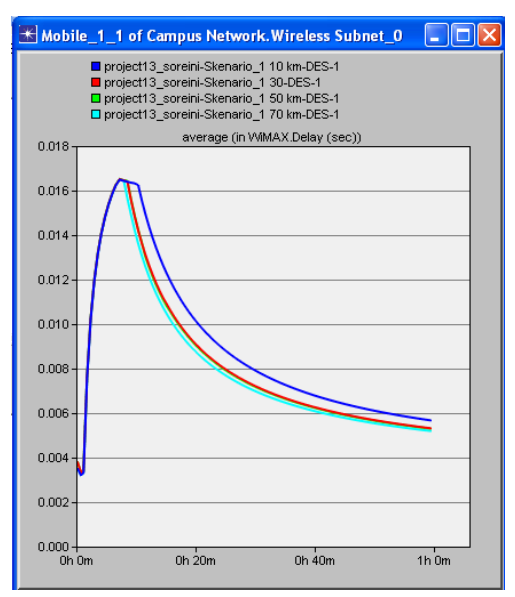

Gambar 16. Delay dengan variasi kecepatan mobile

Dari tabel untuk delay tidak terlihat perbedaan hasil yang diperoleh, namun dari grafik Gambar 12 terlihat perbedaan pada hasil delay yang diperoleh. Dengan memberi variasi kecepatan pada MS maka nilai untuk throughput pada MS pun bervariasi. Hal ini dipengaruhi oleh kecepatan MS ketika melakukan handover dari 1 cell ke cell yang disebelahnya.

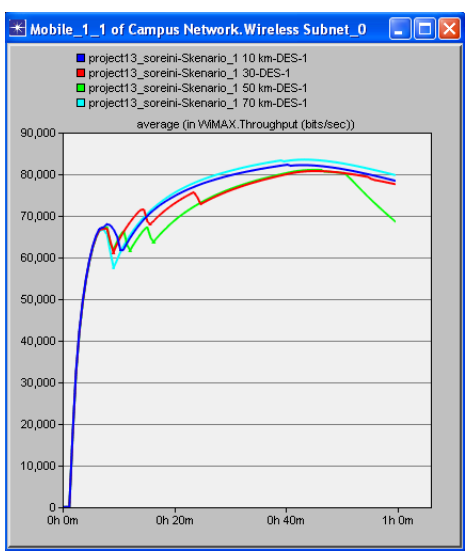

Gambar 17. Throughput dengan variasi kecepatan mobile 
Grafik yang dihasilkan untuk throughput dengan variasi kecepatan terlihat pada Gambar 13. Dari awal simulasi throughput yang terjadi samasama naik dan terjadi penurunan nilai throughput pada menit sekitar 9 sampai 10 menit. Dari Gambar 13 dapat dikatakan bahwa semakin besar kecepatannya maka semakin renggang throughput yang dihasilkan, makin banyak terjadinya penurunan dalam kualitas pelayanan, hal ini dikarenakan adanya delay pada MS.

Tabel 14. Throughput pada variasi kecepatan mobile

\begin{tabular}{|c|c|c|}
\hline $\begin{array}{c}\text { Kecepatan } \\
\text { pada MS }\end{array}$ & Minimum & Maksimum \\
\hline $10 \mathrm{~km} / \mathrm{jam}$ & $44,96 \mathrm{bit} / \mathrm{sec}$ & $81.115 \mathrm{bit} / \mathrm{sec}$ \\
\hline $30 \mathrm{~km} / \mathrm{jam}$ & $39,62 \mathrm{bit} / \mathrm{sec}$ & $80.758 \mathrm{bit} / \mathrm{sec}$ \\
\hline $50 \mathrm{~km} / \mathrm{jam}$ & $49,66 \mathrm{bit} / \mathrm{sec}$ & $80.643 \mathrm{bit} / \mathrm{sec}$ \\
\hline $70 \mathrm{~km} / \mathrm{jam}$ & $57,66 \mathrm{bit} / \mathrm{sec}$ & $83.429 \mathrm{bit} / \mathrm{sec}$ \\
\hline
\end{tabular}

\section{PENUTUP}

\section{A. Kesimpulan}

1. Pada saat terjadi handover dalam simulasi intra $A S N-G W$ tidak ada gangguan yang akan terjadi dan user akan tetap dapat berkomunikasi dengan baik walaupun terjadi handover.

2. Pada intra ASN-GW delay yang terjadi pada BS_1, BS_2, dan MS berturutturut memberikan nilai maksimum 0,029 sec, $0.017 \mathrm{sec}$, dan 0,0161 sec, dan throughput maksimum yang terjadi pada ketiga perangkat berturut-turut untuk BS_1, BS_2, dan MS adalah $80.537 \mathrm{bit} / \mathrm{sec}, 75.626 \mathrm{bit} / \mathrm{sec}$, dan $80.127 \mathrm{bit} / \mathrm{sec}$.

3. Pada inter ASN-GW delay yang terjadi pada BS_1, BS_2, dan MS berturutturut memberikan nilai maksimum 26,69 sec, tidak dapat menampilkan delay, dan 0,0038 sec, untuk nilai delay masih dalam batas standar yang baik dan throughput maksimum yang terjadi pada ketiga perangkat berturut-turut BS_1, BS_2, dan MS adalah sebagai berikut $0 \mathrm{bit} / \mathrm{sec}, 0 \mathrm{bit} / \mathrm{sec}$, dan 0 bit/sec. ini berarti tidak terjadi pengiriman paket data.

4. Handover terjadi pada simulasi intra ANS-GW pada menit ke 12, dari mobile yang melakukan pergerakan terjadi penurunan nilai throughput pada menit 12 namun tidak menyebabkab terjadinya drop call.

\section{B. Saran}

1. Penulis hanya melakukan simulasi pada layanan VoIP, diharapkan di masa yang akan datang dapat melakukan simulasi dengan layanan seperti Video Conference dan layanan Internet.

2. Lebih baik menggunakan software simulasi yang lebih mendukung proses pengerjaan penelitian, penulis merasa Opnet Modeler Simulator kurang mendukung pengerjaan skripsi ini untuk simulasi inter $A S N-G W$, karena grafik yang dihasilkan kurang sesuai dengan yang diharapkan untuk pemakaian 2 ASN, karena layer 2 yang kurang mendukung.

\section{DAFTAR PUSTAKA}

[1] AccessNet.Lab.2010. OPNET Modeler 2010 - Fixed, Mobility and Scheduling on WiMAX

[2] Andrews,Jeffrey G., Arunabha Ghosh., dan Rias Muhamed.Fundamental of WiMAX.

[3] Bandwidth, Throughput, Goodput, http://blog.ub.ac.id/thierry/2011/11/26/ bandwidth-throughput-goodput/

[4] Chapter II, Universitas Sumatera Utara. www.repository.usu.ac.id/bitstream/12 3456789/19840/4/Chapter\%20II.pdf 
[5] Freedom not forsale. Perbedaan Wifi dan WiMAX,

http://freedomnotforsale.blogspot.com/ 2011/03/perbedaan-wifi-danwimax.html

[6] F Lukman,Haldy.2011. Simulasi dan Analisa Kinerja Jaringan Mobile WiMAX pada Proses Hard Handover Berdasarkan Standar IEEE 802.16e. Bandar Lampung;Fakultas Teknik, Universitas Lampung.

[7] HSCTechnicalWiki http://wiki.hsc.com/wiki/Main/Wimax AsnGw

[8] IEEE 802.16e. Amandement 2: Physical and Medium Access Control Layer of Combined Fixed and Mobile Operation ini Lisence Bands, February 2006s

[9] MobileIndonesia.2011.Handover (HO), www.mobileindonesia.wordpress.com/ 2011/02/24/hand-over-ho/

[10] Prihatmoko,Galuh.2009.Mobile Communication Research.Bandung, www.fosilonblog.blospot.com/2009/05 /handover-dan-macam2nya-handoveradalah.html

[11] S.B,Dorado.2010.Teori Dasar GPS, www.dorado.web.ugm.ac.id/tag/teleko munikasi/

[12] Sutanta, Edhy.2005.Komunikasi Data Jaringan Komputer:Jogjakarta.Graha Ilmu.

[13] Wibisono,Gunawan., dan Gunadi Dwi Hantoro.2008.Mobile Broadband Tren Teknologi Wireless Saat Ini dan Masa Datang: Bandung. Informatika.

[14] Yuliansyah,Rizki.2011.Simulasi ASN Gateway Untuk Fungsi DHCP Relay. Bandar Lampung;Fakultas Teknik, Universitas Lampung.

[15] Yu,yongxue.Handover performance in the mobile wimax network. 2009.

Theses and dissertations. paper 99 .
[16] E. Kacerginskis, L. Narbutaite. Capacity and handover analysis in mobile wimax.

[17] Bae, Chul-Min.WIMAX network standards,standardization and technologies. 2007 